\title{
Variations of the aerosol chemical composition during Asian dust storm at Dushanbe, Tajikistan
}

\author{
Khanneh Wadinga Fomba ${ }^{1}$, Konrad Müller ${ }^{1}$, Julian Hofer $^{1}$, Abduvosit N. Makhmudov ${ }^{2}$, Dietrich Althausen ${ }^{1}$, \\ Bahron I. Nazarov², Sabur F. Abdullaev ${ }^{2}$, Hartmut Herrmann ${ }^{1 *}$ \\ ${ }^{1}$ Leibniz Institute for Tropospheric Research (TROPOS), Permoserstr. 15, 04318 Leipzig, Germany \\ ${ }^{2}$ Academy of Sciences of Republic of Tajikistan, Physical-Technical Institute, Department of Physical Atmosphere, Ayni \\ Str.299/1, 734063, Dushanbe, Tajikistan
}

\begin{abstract}
Aerosol chemical composition was characterized during the Central Asian Dust Experiment (CADEX) at Dushanbe (Tajikistan). Aerosol samples were collected during a period of 2 months from March to May 2015 using a high volume DIGITEL DHA-80 sampler on quartz fiber filters. The filters were analyzed for their ionic, trace metals as well as organic and elemental carbon (OC/EC) content. The aerosol mass showed strong variation with mass concentration ranging from $18 \mu \mathrm{g} / \mathrm{m}^{3}$ to $110 \mu \mathrm{g} / \mathrm{m}^{3}$. The mineral dust concentrations varied between $0.9 \mu \mathrm{g} / \mathrm{m}^{3}$ and $88 \mu \mathrm{g} / \mathrm{m}^{3}$. Days of high aerosol mass loadings were dominated by mineral dust, which made up to about $80 \%$ of the aerosol mass while organic matter and inorganic ions made up about $70 \%$ of the aerosol mass during days of low aerosol mass loadings. The mineral dust composition showed different trace metal signatures in comparison to Saharan dust with higher Ca content and $\mathrm{Ca} / \mathrm{Fe}$ ratios twice as high as that observed in Saharan dust. Strong influence of anthropogenic activities was observed in the trace metal concentrations with $\mathrm{Zn}$ and $\mathrm{Pb}$ concentrations ranging from 7 to $197 \mathrm{ng} / \mathrm{m}^{3}$ and 2 to $20 \mathrm{ng} / \mathrm{m}^{3}$, respectively. Mineral dust and anthropogenic activities relating to traffic, combustion as well as metallurgical industrial emissions are identified as the sources of the aerosol during this period.
\end{abstract}

\section{Introduction}

Aerosols are important drivers of atmospheric processes and play an important role in regulating the local weather as well as the long-term climate. Amongst other types of aerosols, mineral dust is quite important due to its radiative forcing and health effects. Mineral dust can be transported over thousands of kilometer from the source region, thereby, affecting air quality over a larger area and across continents [1]. Mineral dust affects cloud radiative and physical properties and alter the hydrological cycle. It can modify atmospheric gaseous composition through heterogeneous reactions and is a source of nutrients to the open oceans [2].

Dust sources have different characteristics depending on the dominant minerals found in the respective arid and desert regions. These minerals on the one hand, have different optical and radiative characteristics. On the other hand, their chemical composition may change due to fractionation during longrange transport, which further influences their impact on the aerosol composition [3]. Aerosol chemical composition, thus, provides important information on the changes of aerosol properties and their subsequent impact on the environment. Central Asian countries are surrounded by many deserts, which are potential dust source regions. The significant impact on the radiative

\footnotetext{
* Corresponding author: herrmann@tropos.de
}

forcing of mineral dust, therefore, requires a closer look into regions of high dust activities for the understanding of the future evolution of dust emissions and their chemical properties. At Dushanbe, studies have observed mixtures of different dust types originating from the Saharan, Middle East and Central Asia [4].

The Central Asian Dust Experiment (CADEX) took place in Dushanbe, Tajikistan. During CADEX, the aerosol chemical properties were investigated to assess the link between aerosol optical properties and mineral dust. Aerosol samples were collected and the chemical composition of the particles were investigated. Here, the results from March to May 2015 are presented.

\section{Experiment}

\subsection{Site and sampling}

The CADEX experiment was performed in Dushanbe, the capital of Tajikistan from March 2015 to August 2016. Tajikistan is a mountainous country in Central Asia that lies in close proximity of many potential dust source regions such as the Taklamakan, Aralkum, Karakum, Kyzylkum, Dasht-e Lut and Kavir deserts. Dushanbe is an urban city with a population of over 800,000 inhabitants and experiences a Mediterranean climate with dry and hot 
summers and chilly but not very cold winters. Due to its location, the city often experiences both mineral dust and anthropogenic emissions that influence its aerosol chemical composition.

During the CADEX experiment, aerosol samples were collected in a $48 \mathrm{~h}$ routine between March and May 2015 at the campus of the Physical-Technical Institute of the Academy of Sciences of Tajikistan located in the eastern region of Dushanbe. The site is situated on a hill, which is about $864 \mathrm{~m}$ a.s.l with coordinates $38^{\circ} 33^{\prime} 34^{\prime \prime} \mathrm{N}$, $68^{\circ} 51$ '22" E [4]. The samples were collected on preheated quartz fiber filters (Munktell, MK 360) at a flow rate of 500 1/min using a high volume DIGITEL DHA-80 sampler equipped with a PM10 inlet. In total, 30 filters were collected during this period. After collection, the samples were stored in a refrigerator and subsequently transported to Leipzig for the laboratory analysis.

\subsection{Laboratory analysis}

The filters were equilibrated for $72 \mathrm{~h}$ under relatively constant conditions of $20^{\circ} \mathrm{C}$ and $50 \%$ relative humidity before and after sampling and weighed with a microbalance (Mod. AT261 Delta Range, MettlerToledo, Switzerland) for the evaluation of the aerosol particle mass.

The filter samples were analyzed for ions $\left(\mathrm{Ca}^{2+}, \mathrm{K}^{+}\right.$, $\left.\mathrm{Mg}^{2+}, \mathrm{Na}^{+}, \mathrm{NH}_{4}^{+}, \mathrm{NO}_{3}^{-}, \mathrm{SO}_{4}^{2-}, \mathrm{F}^{-}, \mathrm{Cl}^{-}, \mathrm{C}_{2} \mathrm{O}_{4}{ }^{2-}\right)$, trace metals (Al, K, Ca, Ti, V, Cr, Mn, Fe, Ni, Cu, Zn, As, Se, Rb, Sr, $\mathrm{Mo}, \mathrm{Sb}, \mathrm{Ba}, \mathrm{Pb}, \mathrm{Ce}$ ) as well as organic and elemental carbon (OC/EC). Ions were measured using standard ion chromatography instrument (ICS 3000, Thermo Fischer Scientific, USA) equipped with an automatic eluent generation and a micro membrane suppression unit. The separation of the anions and cations were done with a combination of chromatographic columns, AG18 and AS $18(2 \mathrm{~mm})$ and CG16 and CS16 (3 mm), respectively. Organic and elemental carbon were analyzed by a twostep thermographic method (C-mat 5500, Ströhlein, Germany) with non dispersive infrared sensor (NDIR) detection. Further details of the sample preparation and analytical method and procedures can be found in the literature [5].

Trace metals were analyzed using a Total Reflection X-Ray Fluorescence (TXRF) instrument, S2 PICOFOX, from Bruker-nano (Berlin AG). For this analysis, a $16 \mathrm{~mm}$ diameter filter was punched out of the DIGITEL filters using a ceramic puncher and digested in an $800 \mu \mathrm{l} 3: 1$ conc. $\mathrm{HNO}_{3}$ : $\mathrm{HCl}$ solution at $80^{\circ} \mathrm{C}$ for $2 \mathrm{~h}$. After cooling, aliquots of $100 \mu \mathrm{L}$ were taken and brought onto the TXRF carrier surface via pipetting $(4 \times 25 \mu \mathrm{L})$. Ga was then added to the sample to serve as an internal standard for the TXRF measurement. Thereafter, the carrier was analyzed for the trace metal using the PICOFOX instrument. Further details of the functionality and quantification of the elements using TXRF is described in the literature [6].

Air mass back trajectory analyses were performed to provide useful hints on various air mass origins using the NOAA HYSPLIT (HYbrid Single-Particle Lagrangian Integrated Trajectory model (http://www.arl.noaa.gov/ ready/hysplit4.html). Back trajectories were calculated from a starting height of $500 \mathrm{~m}$ above ground level for $96 \mathrm{~h}$. The water content of the samples was estimated via the E-AIM (Extended Aerosol Inorganics Model) III model [7].

\section{Results}

\subsection{Aerosol mass concentration}

Aerosol mass concentration showed strong temporal variation with an average concentration of $45 \mu \mathrm{g} / \mathrm{m}^{3}$ and concentrations between 18 and $108 \mu \mathrm{g} / \mathrm{m}^{3}$. As shown in Fig. 1, the background concentration at Dushanbe during March and May lies around $18 \mu \mathrm{g} / \mathrm{m}^{3}$, which is comparable to other Central Asian and European urban cities such as Berlin, Germany [8]. The spikes on the plot as on the $14^{\text {th }}$ and $26^{\text {th }}$ of April represent days of mineral dust outbreaks. The days with low mass concentrations were days of little mineral dust but higher anthropogenic influence on the aerosol composition. The temporal variation is mainly due to changes in local wind directions and influences from different sources.

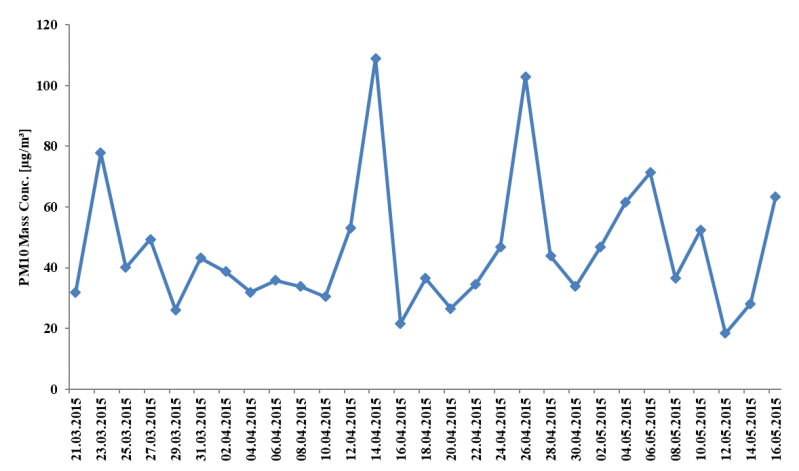

Figure 1. Temporal variation of aerosol mass concentration during March and May 2015 in Dushanbe.

A similar PM10 concentration range has been reported in eastern Tien Shan, Central Asia region [9]. They observed PM10 concentrations between 55 and $92 \mu \mathrm{g} / \mathrm{m}^{3}$ with high concentrations during the spring months due to the high influence of dust storms from the Taklimakan desert. Higher concentrations were reported in Kermanshah, Iran with PM10 concentrations of up to $1 \mathrm{mg} / \mathrm{m}^{3}$ observed during the spring months [10].

\subsection{Aerosol chemical composition}

Table 1 summarizes the chemical components analyzed during the sampling period. The most abundant ions are sulfates and nitrates, followed by calcium, chloride and ammonium with concentrations of up to $4.6 \mu \mathrm{g} / \mathrm{m}^{3}$, $4.5 \mu \mathrm{g} / \mathrm{m}^{3}, \quad 2.9 \mu \mathrm{g} / \mathrm{m}^{3}, 2.4 \mu \mathrm{g} / \mathrm{m}^{3}$ and $2.1 \mu \mathrm{g} / \mathrm{m}^{3}$, respectively. Amongst the investigated components, organic matter and elemental carbon constituted a significant part of the aerosol mass with concentrations 
ranging between $2.2 \mu \mathrm{g} / \mathrm{m}^{3}$ to $11 \mu \mathrm{g} / \mathrm{m}^{3}$ for $\mathrm{OC}$ and $0.7 \mu \mathrm{g} / \mathrm{m}^{3}$ to $3.1 \mu \mathrm{g} / \mathrm{m}^{3}$.

Table 1. Summary of the PM10 aerosol chemical component mass concentrations observed during March and May 2015 at Dushanbe. The minimum (Min), maximum (Max), average (Mean) and standard deviation (Std) values are in $\mathrm{ng} / \mathrm{m}^{3}$. For PM10 and dust, the values are in $\mu \mathrm{g} / \mathrm{m}^{3}$.

\begin{tabular}{|c|c|c|c|c|}
\hline & Min & Max & Mean & Std \\
\hline PM10 & 18.4 & 109 & 45.3 & 22.4 \\
\hline Dust & 0.9 & 88 & 29.5 & 21.0 \\
\hline $\mathrm{Cl}^{-}$ & 64.9 & 2437 & 440.3 & 492.3 \\
\hline $\mathrm{NO}_{3}{ }^{-}$ & 525.3 & 4550 & 1422.8 & 845.0 \\
\hline $\mathrm{SO}_{4}{ }^{2-}$ & 1121.3 & 4672 & 2497.9 & 1065.2 \\
\hline $\mathrm{C}_{2} \mathrm{O}_{4}{ }^{2-}$ & 70.5 & 296 & 140.3 & 43.4 \\
\hline $\mathrm{NO}_{2}^{-}$ & 0.8 & 9 & 4.6 & 1.9 \\
\hline $\mathrm{F}^{-}$ & 5.3 & 523 & 72.6 & 107.9 \\
\hline $\mathrm{Na}^{+}$ & 47.7 & 383 & 149.7 & 78.4 \\
\hline $\mathrm{NH}_{4}^{+}$ & 88.1 & 2089 & 427.8 & 491.5 \\
\hline $\mathrm{K}^{+}$ & 110.6 & 462 & 248.1 & 100.3 \\
\hline $\mathrm{Mg}^{2+}$ & 16.7 & 125 & 57.1 & 23.7 \\
\hline $\mathrm{Ca}^{2+}$ & 20.7 & 2238 & 690.9 & 581.8 \\
\hline $\mathrm{OC}$ & 2232.8 & 1103 & 4207.2 & 1751.1 \\
\hline $\mathrm{EC}$ & 775.0 & 3124 & 1665.7 & 624.8 \\
\hline $\mathrm{Al}$ & 30 & 0.985 & 368.3 & 126.2 \\
\hline $\mathrm{Ti}$ & 0.04 & 43 & 10.6 & 8.1 \\
\hline V & 0.04 & 1 & 0.5 & 0.3 \\
\hline $\mathrm{Cr}$ & 0.2 & 2 & 0.6 & 0.4 \\
\hline $\mathrm{Mn}$ & 2.4 & 15 & 5.9 & 3.2 \\
\hline $\mathrm{Fe}$ & 26.4 & 832 & 211.1 & 149.2 \\
\hline $\mathrm{Ni}$ & 0.2 & 0.9 & 0.4 & 0.2 \\
\hline $\mathrm{Cu}$ & 0.4 & 1.5 & 0.8 & 0.3 \\
\hline $\mathrm{Zn}$ & 7.2 & 198 & 60.8 & 46.7 \\
\hline As & 0.01 & 1 & 0.2 & 0.2 \\
\hline $\mathrm{Se}$ & 0.03 & 0.2 & 0.1 & 0.03 \\
\hline $\mathrm{Rb}$ & 0.3 & 2 & 0.8 & 0.4 \\
\hline $\mathrm{Sr}$ & 0.3 & 11 & 3.0 & 2.5 \\
\hline Mo & 1.1 & 23 & 8.0 & 4.7 \\
\hline $\mathrm{Sb}$ & 0.4 & 22 & 8.2 & 5.9 \\
\hline $\mathrm{Ba}$ & 0.03 & 3 & 0.8 & 1.1 \\
\hline $\mathrm{Ce}$ & \begin{tabular}{|l|}
0.02 \\
\end{tabular} & 3 & 0.8 & 0.6 \\
\hline $\mathrm{Pb}$ & 1.9 & 19 & 7.6 & 4.4 \\
\hline
\end{tabular}

Amongst the trace metals, Al, Fe and $\mathrm{Zn}$ were the most abundant elements with concentrations of up to $0.99 \mu \mathrm{g} / \mathrm{m}^{3}, 0.65 \mu \mathrm{g} / \mathrm{m}^{3}$ and $0.2 \mu \mathrm{g} / \mathrm{m}^{3}$, respectively. These components also showed strong temporal variation as observed by the high standard deviation from their mean values.

\subsection{Temporal variation of the aerosol chemical composition}

Mineral dust mass is estimated as

Dust $=1.16(30.75[\mathrm{Ca}]+1.67[\mathrm{Ti}])$,

where $[\mathrm{X}]$ is the concentration of the elements [6].

As described in section 3.1, the days of high PM10 concentrations were dominated by mineral dust concentrations. Figure 2 shows the relative contribution of the main chemical components to the aerosol mass during days of high dust and less dust load. The $29^{\text {th }}$ of March (less dust) and the $14^{\text {th }}$ of April (dusty day) have been used as examples and for the sake of simplicity, only the main parts are presented on this figure.

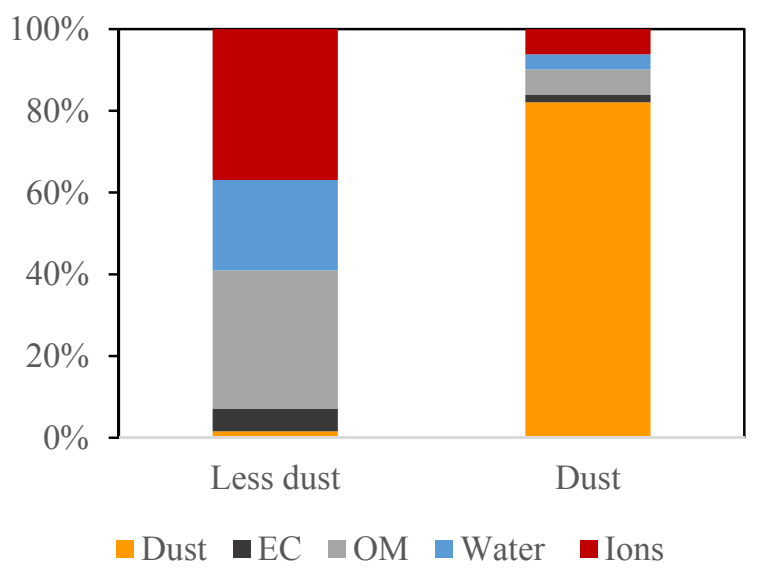

Figure 2. The relative chemical composition of aerosol mass during days of high and low dust concentrations.

The aerosol composition was dominated by ions (mainly sulfates, nitrates and ammonium) during days of low dust loading and they made up about $37 \%$ of the aerosol mass. Organic matter, elemental carbon, aerosol water and mineral dust made up $34 \%, 5 \%, 22 \%$ and $<2 \%$ of the aerosol mass, respectively. In contrast, during days of high dust loads, mineral dust made up about $82 \%$ of the aerosol mass followed by ions $(6 \%)$, organic matter $(6 \%)$, aerosol water $(4 \%)$ and elemental carbon $(2 \%)$. The differences in the aerosol chemical composition between these days suggest that Dushanbe experiences within few days frequent changes in the source of the aerosol particles.

According to air mass back trajectory analysis, during the $14-16^{\text {th }}$ April 2015, the air mass originated from the west and travelled over potential dust source regions such as the Karakum, Kavir, Lut deserts. During days of low dust loads (29-31 March 2015) the air masses originated mainly from the South, thereby suggesting that southerly air masses carry less mineral dust compared to westerly winds due to the differences in the location of the potential dust source regions.

Figure 3 shows the temporal variation of mineral dust and $\mathrm{EC}, \mathrm{Pb}$ and $\mathrm{Zn}$, respectively, whereby $\mathrm{EC}, \mathrm{Pb}$ and 
$\mathrm{Zn}$ are mainly emitted from anthropogenic activities. Days of high mineral dust loads were often different from days of high anthropogenic emissions whereby higher concentrations of $\mathrm{EC}, \mathrm{Pb}, \mathrm{Zn}$ were observed.

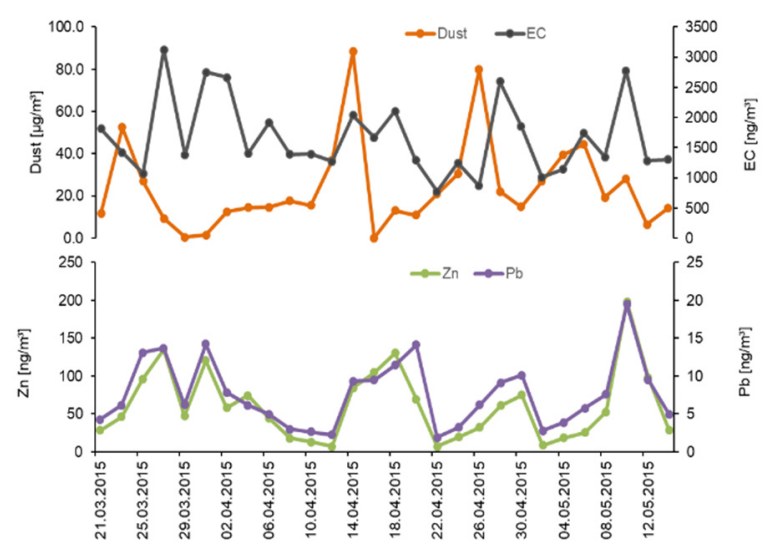

Figure 3. Temporal variation of dust, $\mathrm{EC}, \mathrm{Zn}$ and $\mathrm{Pb}$ showing differences in periods of dust and anthropogenic emissions

This suggests that air parcels with mineral dust observed during days of high dust loadings did not have enough interaction with polluted air masses prior to their transport to eastern Dushanbe. On the other hand, during days of relatively high concentrations of anthropogenic chemical components, little mineral dust was observed. Dust observed during these days were likely related to fugitive dust originating from urban activities such as traffic, building construction or soil resuspension from arid regions in the neighborhood.

\subsection{Correlation between chemical components}

Different correlations were observed between the various chemical components that suggest the different sources. As indicated in Fig. 3, there was not a good correlation between mineral dust and $\mathrm{Zn}, \mathrm{Pb}$ or EC. However, good correlations were observed between elements typical of crustal matter and dust. The correlation between $\mathrm{Ti}, \mathrm{Fe}$, $\mathrm{Al}$ and $\mathrm{Ca}$ was strong with $\mathrm{r}^{2}>0.85$ indicating that these elements were predominantly originating from mineral dust as well as crustal matter. However, the average ratios during dust outbreaks between these crustal metals differ from those observed for Saharan dust. $\mathrm{Ca} / \mathrm{Fe}$ (2.45), $\mathrm{Ca} / \mathrm{Ti}$ (45.1) were 3 to 5 times higher than similar ratios reported during Saharan dust outbreaks [11]. This indicates that Central Asian dust observed at Dushanbe is significantly higher in its calcium content in comparison to Saharan dust. Good correlations were also observed between $\mathrm{Pb}$, $\mathrm{Zn}$, Se and EC with $\mathrm{r}^{2}>0.9$. This suggests that these metals could be linked with anthropogenic emissions from coal combustion processes. Similarly, $\mathrm{r}^{2}>0.85$ was observed between $\mathrm{V}$, Ni suggesting their oil combustion origin. Correlations $\left(\mathrm{r}^{2}>0.6\right)$ were also observed between $\mathrm{Zn}, \mathrm{Cu}, \mathrm{Fe}, \mathrm{Cr}$, suggesting that these elements could have been from traffic as well as metallurgical sources.

\section{Conclusion}

Aerosol chemical composition in Dushanbe was characterized over a period of two months in 2015. Aerosol mass was dominated by mineral dust, organic matter and secondary inorganic aerosols. The measurements showed strong temporal variation in the aerosol mass and chemical components with peak concentrations of about $110 \mu \mathrm{g} / \mathrm{m}^{3}$ observed during days of dust outbreak. The temporal variation was linked with changing meteorological conditions that led to different air mass inflows to Dushanbe. Air masses during dust outbreaks were related to westerly and southwesterly winds that travel over the Karakum, Lut and Kavir deserts, which are potential dust source areas. Mineral dust observed in Dushanbe is richer in its calcium content in comparison to Saharan dust. Good correlations were observed between $\mathrm{Pb}, \mathrm{Zn}$ and $\mathrm{Se}$, between $\mathrm{V}$ and $\mathrm{Ni}$, as well as between $\mathrm{Zn}, \mathrm{Cu}, \mathrm{Fe}$, and $\mathrm{Cr}$. We conclude that these metals were of coal and oil combustion as well as from traffic and metallurgical industries. The sources of aerosol particles in Dushanbe were thus of natural and anthropogenic origins with a strong temporal variation observed between their influences.

\section{References}

[1] J.M. Prospero and R.T. Nees, Nature 320, 735-738 (1986)

[2] T.D. Jickells, Z.S. An, K.K. Andersen, A.R. Baker, G. Bergametti, N. Brooks, J.J. Cao, P.W. Boyd, R.A. Duce, K.A. Hunter, H. Kawahata, N. Kubilay, J. laRoche, P.S. Liss, N. Mahowald, J.M. Prospero, A.J. Ridgwell, I. Tegen, R. Torres, Science 308, 67-71 (2005)

[3] E. Journet, Y. Balkanski, and S.P. Harrison, Atmos. Chem. Phys. 14, 3801-3816 (2014)

[4] J. Hofer, D. Althausen, S.F. Abdullaev, A.N. Makhmudov, B.I. Nazarov, G. Schettler, R. Engelmann, H. Baars, K.W. Fomba, K. Müller, B. Heinold, K. Kandler, A. Ansmann, Atmos. Chem. Phys. 17, 14559-14577 (2017)

[5] K.W. Fomba, K. Müller, D. van Pinxteren, L. Poulain, M. van Pinxteren, H. Herrmann, Atmos. Chem. Phys. 14, 8883-8904 (2014)

[6] K.W. Fomba, D. van Pinxteren, K. Müller, G. Spindler, H. Herrmann, Atmos. Environ. 176, 60-70 (2018)

[7] S.L. Clegg, P. Brimblecombe, and A.S. Wexler, J. Phys. Chem. A 102, 2155-2171 (1998)

[8] W. Wieprecht, M. Lutz, A. John, C. Lüdtke, D. Möller, K. Acker, J. Aerosol Sci. 35, 453-464 (2004)

[9] S.J. Wang, M.J. Zhang, M.C. Minguillon, X.Y. Zhang, F. Feng, X. Qiu, Environ. Sci. Pollut. R. 22, 6864-6876 (2015)

[10]K. Sharafi, T. Khosravi, M. Moradi, M. Pirsaheb, Journal of Engineering Science and Technology 10, 47-56 (2015)

[11]P. Formenti, W. Elbert, W. Maenhaut, J. Haywood, M.O. Andreae, J. Geophys. Res. Atmos. 108 (2003) 